\title{
Kajian Sosioreligi Nilai-Nilai Upacara Aruh Baharin Dalam Masyarakat Dayak Meratus Halong Kabupaten Balangan Sebagai Sumber Pembelajaran Nilai Berbasis Multikultural
}

\author{
Rydho Bagus Pratama ${ }^{1}$ dan Abraham Nurcahyo ${ }^{2}$ \\ ${ }^{1}$ Program Studi Pendidikan Sejarah, FKIP, Universitas PGRI Madiun \\ ${ }^{2}$ Program Studi Pendidikan Sejarah, FKIP, Universitas PGRI Madiun
}

\begin{abstract}
Abstrak
Penelitian ini bertujuan untuk menyatakan bagaimana nilai-nilai positif dalam sistem religi dari budaya lokal Dayak Meratus Halong. Penelitian ini, juga menekankan pada aspek nilai-nilai positif dari budaya, adat-istiadat, dan kearifan lokal dari suku Dayak Meratus Halong. Hal tersebut termanifestasikan dalam sistem religi yang dinamakan sebagai Aruh baharin. Pembahasan tentang nilai-nilai upacara aruh baharin dalam masyarakat dayak meratus halong dijelaskan dengan menggunakan pendekatan kualitatif, dimana jenis penelitian yang digunakan adalah kualitatif-deskriptifyaitu jenis penelitian yang ditujukan untuk mendeskripsikan atau menggambarkan fenomena yang ada, baik secara alamiah atau rekayasa buatan manusia. Teknik pengumpulan data menggunakan observasi, wawancara, dan dokumentasi. Teknik analisis data meliputi tahap reduksi data, tahap penyajian data, dan tahap penarikan kesimpulan. Hasil dari penelitian ini adalah Aruh baharin adalah sebuah hajatan besar atau pesta panen padi yang diadakan oleh masyarakat Dayak Meratus Halong. Prosesi upacara aruh baharin berlangsung pada empat tempat pemujaan, salah satu tempat terpenting bagi masyarakat Dayak Meratus Halong adalah dibalai adat Sarumpun. Kegiatan dibalai adat, upacara aruh baharin berlangsung dengan skala yang lebih besar. Prosesinya diadakan selama 7 hari siang dan malam. Sedangkan untuk skala yang lebih kecil lagi, diadakan dirumah warga secara pribadi selama 3 hari siang dan malam. Prosesi puncak dari ritual upacara aruh baharin terjadi pada malam ketiga hingga keenam, di mana para balian melakukan proses batandik (menari) mengelilingi tempat pemujaan dengan diiringi oleh bunyi-bunyian alat musik tradisional berupa gamelan.
\end{abstract}

\section{Kata Kunci: Aruh Baharin, Dayak Meratus Halong}

\section{Pendahuluan}

Pendidikan dan nilai adalah dua unsur yang memiliki pemaknaan yang berbeda. Jika, pendidikan adalah unsur yang bertujuan mencerdaskan, sedangkan nilai adalah inti dari unsur-unsur yang berada dalam pendidikan. Secara substansial, pendidikan merupakan suatu proses dalam belajar dan mengajar agar orang dapat berfikir secara arif serta bijaksana di setiap prilakunya. Oleh sebab itu, pendidikan merupakan sarana terpenting dalam mewujudkan cita-cita bangsa (Magdalia
Alfian, 2011: 1). Pendidikan juga adalah bagian terpenting dari proses pembentukan karakter pada diri manusia. Karakter yang dimaksud berupa tingkah laku dan cara berfikir yang terbentuk pada diri manusia setelah mengalami sendiri proses di dalam dunia pendidikan.

Selama berabad-abad peradaban manusia, seolah tidak henti-hentinya pendidikan dalam berbagai bentuk dan metodenya telah menjalankan peranan penting untuk menjadikan manusia dari yang tidak mengetahui kemudian dapat 
tercerahkan akal dan budinya. Dalam proses tercerahkan itu tentu, aplikasinya akan tertuang di berbagai model bentuk perilaku yang manusia jalankan. Misalnya dalam sifat, karakter, pribadi, moral, dan nilai yang dianutnya, serta prinsip yang ia jalankan. Tercerahkannya individu tersebut tidak lepas dari pengaruh keluarga, teman, dan instansi pendidikan yang telah menjadi input, sistem proses, hingga outputnya dalam membentuk manusia tersebut.

Jadi, dalam konteks ini pendidikan berperan penting untuk mengubah dan membentuk karakter pada diri manusia. Nilai atau value merupakan suatu sifat yang menyenangkan, memuaskan, menarik, berguna, dan menguntungkan (Al Muchtar dalam Jurnal Pendidikan Sosiologi dan Humaniora). Pandangan ini sejalan dengan pendapat Rokeah, bahwa nilai adalah hal yang berharga, bernilai, adil, baik, benar, dan indah serta menjadi pedoman atau pegangan pada diri manusia (Endang Purwaningsih, 2010: 44).

Pedoman atau pegangan diri muncul karena termaknainya nilai dalam diri manusia yang menjunjungnya. Nilai tentu erat hubungannya dengan manusia, baik dalam bidang etika yang mengatur aktivitas kehidupan manusia di dalam kehidupan sehari-harinya, ataupun di dalam bidang estetika yang berhubungan dengan keindahan. Nilai akan masuk bilamana manusia memahami agama, kebudayaan, dan seni serta kearifan lokal yang memiliki keindahan dan tentu bermanfaat pada diri manusia tersebut (Elly M Setiadi, dkk, 2006: 109-110). Oleh karena itu, nilai tentunya dapat dijadikan sebagai pedoman (falsafah) atau pegangan hidup. Kehidupan modern sebagai dampak kemajuan dalam berbagai bidang, yaitu pengetahuan dan teknologi. Hal itu menghasilkan berbagai perubahan, pilihan dan kesempatan, tetapi mengandung berbagai macam resiko yang ditimbulkannya akibat permasalahan kehidupan yang semakin hari, semakin kompleks.

Salah satu permasalahan yang ditimbulkan adalah munculnya nilai-nilai modern yang tidak jelas. Nilai-nilai tersebut, berpotensi untuk membingungkan peserta didik dan dapat berdampak pada degradasi moral (Elly M Setiadi, dkk, 2006: 126-127). Degradasi moral ini, terlihat pada aksi pawai sepeda motor yang dilakukan oleh peserta didik dalam euforia kelulusan sekolah pada jenjang Sekolah Menengah Atas/Kejuruan (SMA/SMK) dengan mencoret-coret baju.

Di tambah lagi, bukan hanya peserta didik yang mengalamai degradasi moral namun, para pemangku kebijakan pun tidak luput dengannya. Dalam hal ini, seperti semakin bobroknya moral para pejabat negara yang melakukan tindakan korupsi ataupun segala macam bentuk penyelewangan, sampai saat ini belum dapat tertangani secara memuaskan oleh institusi negara. Dewasa ini beragam mecam 
bentuk kehancuran moral, nyaris dapat kita ditemui baik pada lapisan masyarakat ataupun pada semua dimensi kehidupan politik, sosial, dan ekonomi serta pendidikan (Endang Purwaningsih, 2010: 45-46). Pendidikan nilai dalam konteks saat ini, relevan sebagai alternatif dalam mengatasi problematika moral yang saat ini sedang melanda negeri ini.

Krisis moral tersebut diantaranya berupa meningkatnya angka pergaulan bebas pada peserta didik, maraknya angka kekerasan terhadap anak, penyalahgunaan obat-obatan terlarang, pornografi, dan konflik berbasis SARA umumnya telah menjadi permasalahan sosial. Hal tersebut, tentu telah menjadi permasalahan sosial yang kompleks dan sulit untuk diatasi secara tuntas. Di antara deretan faktor tersebut, yang turut mengkondisikan terjadinya berbagai kasus degradasi moral, penyelengaraan pendidikan nasional dituding turut menjadi penyebab munculnya masalah-masalah tersebut.

Dalam konteks ini, akan muncul pernyataan mendasar bagaimana sebenarnya peran pendidikan nasional kita sebagai landasan nilai dalam meletakkan pondasi moral dan peradaban masyarakat? (Sulton, 2015: 37-38). Kepulauan Indonesia yang berada disebelah barat Samudera Hindia dan disebelah timur Samudera Pasifik memiliki lebih dari tiga ribu pulaupulau besar dan kecil (M. Idwar Saleh, Tanpa Tahun: 15), di antara pulau itu sendiri hidup ratusan suku-bangsa yang beraneka ragam: Di dalam ensiklopedia yang ditulis oleh M. J. Malalatoa telah terdokumentasi tidak kurang terdapat 514 macam suku bangsa yang beraneka ragam dari budaya hingga sistem religi, mendiami kepulauan Indonesia (Meutia F Swasono, 2006: 109). Sedangkan menurut Parsudi Suparlan, diperkirakan terdapat lebih dari 500 suku bangsa yang hidup di kepulauan Indonesia.

Suku bangsa tersebut, memiliki corak keanekaragaman budaya dan tingkat kebudayaannya masing-masing (Parsudi Suparlan, 2000: 3). Beragamnya macam dari suku-bangsa tersebut, terlihat dari tujuh unsur budaya yang mereka miliki masingmasing: Ketujuh unsur kebudayaan itu mencakup: 1). Bahasa; 2). Sistem pengetahuan; 3). Organisasi sosial; 4). Sistem peralatan hidup dan teknologi; 5). Sistem mata pencarian hidup; 6). Sistem religi; dan 7). Kesenian (Koentjaraningrat, 2002: 203-204). Oleh, karena itu Indonesia dapat dikategorikan sebagai nagara multikultur.

Dari kesemua suku-bangsa tersebut, dapat dicontohkan beberapa, yaitu: suku Aceh, Batak, Minahasa, Dayak, Bugis, Banjar, Jawa, Sunda, Minangkabau, Papua dan masih banyak lagi. Budaya lokal yang berasal dari Indonesia sejatinya terkandung nilai-nilai positif yang tentu dapat diintegrasikan ke dalam pendidikan. Hal tersebut diperuntukan agar membenahi 
moral dan dapat menjadi landasan nilai pada peserta didik. Nilai-nilai kebangsaan dan budaya lokal adalah dua aspek penting yang seharusnya telah ditanamkan sejak dini dalam proses pendidikannya. Penerapan pendidikan nilai ini, ialah dengan menanamkan nilai kepada peserta didik, namum lebih pada proses menggali atau mengekplorasi dan mengembangkan nilainilai pada pendidikan.

Menggali dan mengeksplorasi budaya lokal adalah hal yang tepat untuk diintegrasikan ke dalam proses pendidikan yang berbasis pada nilai-nilai budaya lokal. Hal itu, dapat digunakan sebagai proses untuk membantu peserta didik dalam upaya untuk mengeksplorasi nilai-nilai yang ada melalui proses pengujian kritis, sehingga peserta didik dimungkinkan untuk sedapat mungkin meningkatkan atau memperbaiki kualitas berpikir serta perasaan yang ia miliki (Endang Purwaningsih, 2010: 46).

Etnis Dayak Meratus dalam sebuah dokumentasinya adalah sebuah nama kolektif bagi sebagian sub-suku Dayak yang mendiami pulau Kalimantan, lebih tepatnya di provinsi Kalimantan Selatan. Etnis ini mendiami wilayah-wilayah disekitaran sungai, perbukitan, lembah-lembah sempit, dan kawasan hutan lindung pegunungan di Meratus di daerah Kabupaten Balangan, Hulu Sungai Tengah, Hulu Sungai Selatan, Tapian, Banjar, Tanah Laut dan Kotabaru. Dahulu dan dalam sebagian besar publikasi, etnis Dayak Meratus dikatakan sebagai etnis
(Dayak) Bukit (Wajidi, 2013: 89-90). Ada beberapa sub suku Dayak Meratus yang tinggal dipegunungan meratus di wilayah Kabupaten Balangan. Sub suku tersebut, meliputi Dayak Meratus Balangan (Halong), Dayak Bukit, dan Dayak Pitap (Hartatik, 2017, 20-21). Suku Dayak Meratus Halong yang berada di Kalimantan Selatan memiliki budaya yang unik. Keunikan tersebut terdapat dalam nilai-nilai budaya mereka.

Nilai positif yang terkandung di dalam budaya mereka yaitu seperti: kejujuran, menghargai dan menghormati roh padi, menjaga hutan secara turuntemurun, mengedepankan kemaslahatan bagi sesama umat manusia, toleransi terhadap perbedaan agama yang telah menjadi keniscayaan (pluralisme). Dalam ritus mereka terdapat budaya Bahuma (berladang) yaitu sistem religi yang dipadukan dengan tradisi berladang. Puncak daripada tradisi ini adalah Aruh baharin dalam istilah orang Dayak Meratus Halong. Nilai-nilai keyakinan seperti kejujuran, mengedepankan kemaslahatan sesama, dan toleransi beragama kiranya relevan dalam kondisi saat ini.

Masyarakat Dayak Meratus Halong pada dasarnya memiliki tiga nilai-nilai budaya yaitu nilai keyakinan atau kepercayaan, nilai sosial, dan nilai budaya. Ketiga nilai-nilai tersebut adalah satu kesatuan yang utuh dan tidak dapat terpisahkan pada tradisi budaya dan kearifan masyarakat mereka. Pada sistem 
religi, masyarakat Dayak Meratus Halong telah mengenalkan nilai-nilai toleransi, menghargai sesamanya meskipun berbeda kepercayaan dan mengedepankan kemaslahatan sesama. Di era saat ini nilainilai toleransi, menghargai sesamanya dan mengedepankan kemaslahatan buat sesama di rasa minus.

Masyarakat modern saat ini, lebih menyukai persoalan yang praktis serta berfikir pragmatis terhadap berbagai macam hal dalam aspek kehidupannya. Dari hal tersebut, telah memunculkan sifat-sifat individualisme dalam sendi-sendi masyarakat kita. Masalah-masalah sosial seperti halnya konflik yang berlatarbelakang SARA adalah segelintir contoh dari kurang termaknainya nilai-nilai toleransi dan keberagaman pada masyarakat kita dewasa ini. Telah tercatat dalam sejarah bahwa begitu banyak konflikkonflik yang berbasis SARA di Indonesia.

Misalnya dalam konflik yang berbasis SARA tersebut, dapat dicontohkan seperti: 1). Konflik budaya antara orang Sunda dan orang Jawa di daerah Bandung pada tahun 1969-70, dikarenakan dominasi kebudayaan Jawa yang dominan di wilayah Bandung memaksa orang-orang Sunda untuk memusuhinya. 2). Konflik antara masyarakat Ambon yang Kristen dengan Ambon yang Islam ditambah Buton, Bugis, Makassar (BBM) di era Orde Baru. 3). Dan, lalu konflik antar etnis yang terjadi di wilayah Kabupaten Sambas antara orang suku Melayu-Dayak dengan suku Madura (Parsudi Suparlan, 1999: 16-18). Bahkan, untuk kasus di Kabupaten Sambas ini setelah berakhirnya konflik tersebut, orangorang Madura yang hidup disana diusir oleh orang-orang Melayu Sambas, dikarenakan orang-orang Melayu Sambas mengambil kebijakan politik kesukubangsaan yang sempit memutuskan untuk tidak menerima kembali orang-orang Madura (Parsudi Suparlan, 2001: 8).

Jika hal ini terjadi terus, maka berdampak buruk pada generasi penerus bangsa. Menjadi penting di dalam konteks ini untuk mengunakan nilai-nilai budaya lokal terkhusus pada nilai-nilai di dalam sistem religi budaya Dayak Meratus Halong dalam memperbaiki moral dan menjadi landasan nilai pendidikan untuk memahami betapa pentingnya keberagaman bangsa.

\section{Tinjauan Pustaka}

\section{A. Makna Pendidikan Nilai}

Pembelajaran tentang nilai-nilai secara mudah dapat dihubungkan ke dalam bidang-bidang belajar, seting belajar ataupun model belajar. Kerapkali sebuah diskusi tentang suatu subjek atau materi pelajaran yang sedang dipelajari di dalam kelas, mengarah pada diskusi tentang nilai. Menurut pendapat Kaswardi (dalam Jurnal Pendidikan Sosiologi dan Humaniora, 2010: 46) yang dimaksud dengan pendidikan nilai adalah penanaman dan pengembangan suatu nilai-nilai kepada diri seseorang. 
Pembelajaran yang berbasiskan pada nilainilai dapat pula diselipkan bilamana terjadi konflik antar peserta didik. Pembelajaran ini juga berguna sebagai sebuah edukasi dari proses mediasi pencegahan konflik dalam skala yang lebih kecil dilingkungan peserta didik. Situasi-situasi itu, dapat digunakan sebagai upaya dalam mengeksplorasi nilainilai lebih lanjut.

Intinya menciptakan sebuah atmosfer berbasis nilai dalam proses belajar dan mengajar amatlah penting. Hal tersebut, bertujuan untuk eksplorasi optimal dan pengembangan nilai-nilai peserta didik dan generasi muda (Sulton, 2015: 38-76). Pendidikan nilai digunakan sebagai suatu proses dalam membantu peserta didik mengeksplorasi nilai-nilai yang ada. Prosesnya melalui pengujian kritis, sehingga peserta didik dimungkinkan sedapat mungkin untuk mampu meningkatkan ataupun memperbaiki kualitas berfikir serta perasaannya.

Pendidikan nilai bertujuan untuk pembentukan karakter atau akhlak dengan materi yang menyangkut moralitas nilainilai (values). Hal itu, tentunya memerlukan metode dan strategi khusus dalam penerapannya kepada peserta didik (Endang Purwaningsih, 2010: 46). Menurut Aspin (dalam Jurnal Pendidikan Sosiologi dan Humaniora, 2010: 46) pendidikan nilai berguna sebagai bantuan untuk mengembangkan dan mengartikulasikan kemampuan pertimbangan nilai ataupun keputusan moral yang dapat melembagakan kedalam suatu kerangka tindakan manusia. Sedangkan menurut Supiadi (dalam Jurnal Pendidikan Sosiologi dan Humaniora, 2010: 46), menjelaskan bahwa pendidikan nilai mencakup suatu keseluruhan aspek pengajaran atau bimbingan kepada peserta didik agar menyadari apa yang dimaksud dengan nilai kebenaran, nilai kebaikan, dan nilai keindahan.

Hal tersebut, dapat dicapai melalui serangkaian proses pertimbangan nilai yang tepat dan baik serta pembiasaan bertindak untuk membangun sikap konsisten yang peserta didik harus genggam. Konsep awal tentang pendidikan nilai ialah sebuah komponen yang menyentuh nilai filosofi dari tujuan pendidikan. Maksudnya yaitu untuk memanusiakan manusia, lalu membangun manusia yang paripurna dan membentuk insan kamil serta membentuk manusia yang bermartabat.

Dalam ranah pendidikan nilai, seorang pendidik atau guru tidak hanya aktif di dalam serangkaian kegiatan belajar dan mengajar di ruang kelas, tetapi lebih pada proses relasi pribadinya kepada peserta didik maupun keseluruhan anggota komunitas sekolah dimana dia mengajar. Relasi ini berkembang secara peset dan menghasilkan buah-buah pendidikan bilamana dilandasi dengan kasih sayang yang tulus antar sesama mereka. Sebuah pribadi dapat berkembang secara optimal dan relatif tanpa suatu hambatan bilamana 
berada dalam suasana yang penuh kasih sayang, hati yang penuh pengertian serta relasi pribadi yang efektif kepada sesamanya. Sikap seperti ini yang ingin dilahirkan dalam pedidikan nilai. Jadi, konsep pendidikan nilai sejatinya menekankan kepada aspek positif untuk membangun manusia yang arif dan bijaksana serta berfikiran lebih maju dalam menjalani kehidupan.

\section{B. Asal-usul Suku Dayak Meratus Halong}

Tradisi Suku Dayak Meratus adalah nama sebuah suku-bangsa yang mendiami pulau terbesar di kepulauan Indonesia yaitu Kalimantan, lebih tepatnya di Kalimantan Selatan. Secara geografis suku ini mendiami wilayah sungai, perbukitan, lembah-lembah sempit, serta kawasan hutan lindung dipegunungan Meratus. Daerah pemukiman mereka tersebar dan meliputi beberapa wilayah disekitaran Kabupaten Balangan, Hulu Sungai Tengah, Hulu Sungai Selatan, Tapian, Banjar, Tanah Laut dan Kotabaru. Pada sebagian besar publikasinya, etnis Dayak Meratus disebut-sebut sebagai etnis (Dayak) Bukit.

Secara administratif, wilayah hunian tradisional dari Dayak Meratus di antara lain termasuk ke dalam Kecamatan Halong dan Kecamatan Awayan di Kabupaten Balangan, Kecamatan Batang Alai Timur dan Kecamatan Hantakan di Kabupaten Hulu Sungai Tengah, Kecamatan Loksado di Kabupaten Hulu Sungai Selatan, Kecamatan
Piani di Kabupaten Tapian, Kecamatan Paramasan di Kabupaten Banjar, Kecamatan Kintap di Kabupaten Tanah Laut, Kecamatan Sampanahan dan Kecamatan Kelumpang Hulu di Kabupaten Kotabaru (Wajidi, 2013: 89-90). Ada beberapa sub suku Dayak Meratus yang tinggal dipegunungan Meratus di wilayah Kabupaten Balangan. Sub suku tersebut, meliputi Dayak Meratus Balangan (Halong), Dayak Bukit, dan Dayak Pitap.

Ketiga sub suku ini sebenarnya merupakan bagian dari Dayak Meratus. Dayak Meratus Balangan (Halong) diartikan sebagai orang Dayak yang tinggal disekitaran aliran sungai Balangan, Dayak Bukit tinggal dipegunungan bagian atas, sedangkan Dayak Pitap tinggal di sekitar aliran sungai Pitap (Hartatik, 2017: 20-21). Etnis Dayak Meratus, jika dibandingkan dengan seluruh populasi Etnis Dayak yang hidup di pulau Kalimantan adalah sebagaian kecil dari Dayak lain, yang mendiami pulau Kalimantan.

Menurut Tjilik Riwut (dalam Jejak Budaya Dayak Meratus Dalam Perspektif Etnologi, 2017: 15), menjelaskan bahwa suku Dayak di Kalimantan terdiri dari 7 suku besar, dari ketujuh suku besar tersebut terbagi menjadi 18 suku sedatuk, kemudian dari kedelapan belas suku sedatuk terbagi lagi ke dalam 405 suku kekeluargaan. Ketujuh suku Dayak besar di Kalimantan yaitu, terdiri dari Dayak Ngaju, Apu Kayan, Iban, Klemantan, Murut, Punan, dan Ot 
Danum. Sebagai suku besar, Dayak Ngaju terbagi lagi menjadi 4 suku kecil yaitu, terdiri dari Dayak Ngaju, Ma'ayan, Dusun, Lawangan.

Dari suku kecil Dayak Ngaju tebagi lagi menjadi 53 sub suku atau suku kekeluargaan, Dayak Ma'ayan menjadi 8 sub suku kecil kekeluargaan, dan Dayak Lawangan terbagi lagi menjadi 21 sukusuku kecil, serta salah satu di 53 sub suku tersebut diantaranya adalah Dayak Meratus.

\section{Tradisi Religi Aruh Bahrain}

Aruh Baharin merupakan hajatan besar yang paling ditunggu, direncanakan dengan matang jauh sebelumnya. Pada hakikat upacara ini merupakan suatu ungkapan rasa syukur atas panen pertama diladang baru. Orang Dayak Balangan melakukannya sekitar bulan September sampai dengan Oktober, dilakukan secara bersama-sama perkelompok adat atau umbun. Proses dari upacara aruh baharin berlangsung selama 7 hari 7 malam, yang dipimpin oleh lima hingga sepuluh orang balian. Dalam proses upacara adat ini selain anggota umbun, orang diluar kelompok umbun dari berbagai daerah, hingga pejabat dari instansi diundang untuk datang menyaksikan pesta adat tersebut (Hartatik, 2017: 29).

\section{Metode Penelitian}

Penelitian ini dilakukan di Desa Kapul Kecamatan Halong Kabupaten Balangan Kalimantan Selatan. Alasan dipilihnya lokasi tersebut karena kecamatan ini adalah salah satu wilayah konsentrasi hunian dari etnis Dayak Meratus. Pendekatan penelitian ini adalah kualitatifdeskriptif. Pendekatan kualitatif berupaya untuk menyelidiki suatu fenomena dan permasalahan sosial manusia. Sedangkan penelitian deskriptif digunakan untuk memecahkan ataupun menjawab permasalahan sosial yang sedang dihadapi pada situasi saat ini (Hamid Darmadi, 2014: $184 \& 287)$.

Pendekatan penelitian kualitatifdeskriptif berusaha untuk memusatkan perhatiannya kepada permasalahan aktual, dalam hal ini peneliti berusaha untuk mendiskripsikan suatu peristiwa atapun suatu kejadian yang menjadi objek dari pusat perhatian. Hasilnya dapat digunakan untuk menjawab ataupun memecahkan permasalahan aktual di dalam kehidupan sosial masyarakat. Penelitian ini menggunakan jenis studi penelusuran kembali. Sebab fenomena yang diteliti telah berlangsung pada bulan September s/d Oktober 2017. Hasil dari penelitian ini nantinya, dapat digunakan sebagai model pendidikan nilai yang berlandaskan pada nilai budaya lokal dan potensinya bagi pendidikan multikultural.

Sumber data yang digunakan dalam penelitian ini adalah: 1). Sumber Data Primer. Sumber data primer merupakan sumber data penelitian yang diperoleh secara langsung dari asalnya. Sumber dat 
ini, tidak didapat melalui media perantara. Data primer yang digunakan adalah catatan resmi, foto dan hasil wawancara informan.

Contoh sumber data primer yang peneliti dapatkan, sebagai berikut: a). Fotofoto kegiatan upacara Aruh Baharin tahuntahun terdahulu, dan b). Wawancara kepada tokoh-tokoh adat setempat, yaitu kepada balian (pemimpin upacara adat keagamaan), ketua adat, dan masyarakat pendukung kebudayaan Dayak Meratus Halong. 2). Sumber Data Sekunder. Sumber data sekunder merupakan data yang diperoleh oleh peneliti secara tidak langsung. Hal tersebut didapat melalui perantara pihak lain. Data sekunder umumnya berupa bukti dan catatan ataupun laporan yang telah tersusun di dalam arsip.

Data sekunder dalam penelitin ini berupa catatan yang tidak sejaman, bukubuku tentang Dayak Meratus Halong dan pustaka lain yang relevan. Data sekunder yang peneliti gunakan, sebagai berikut:

a. Buku berjudul Jejak Budaya Dayak Meratus Dalam Perspektif Etnoreligi karya Hartatik yang diterbitkan pada tahun 2017 oleh Penerbit Ombak.

b. Buku berjudul Sejarah, Etnisitas, Dan Kebudayaan Banjar karya Norpikriadi yang diterbitkan pada tahun 2015 oleh Penerbit Ombak.

c. Buku berjudul Ritual Adat \& Cerita Rakyat Dayak Halong karya Eter Nabiring yang diterbitkan pada tahun 2018 oleh
Penerbit Kota Tua \& Nomaden Institute Cross Cultural Studies.

d. Buku berjudul Kamus Populer Dayak Balangan karya Eter Nabiring yang diterbitkan pada tahun 2013 oleh Dewan Adat Dayak Balangan.

e. Buku berjudul Dayak Halong Balangan; Merawat Tradisi Leluhur Menjaga Yang Tersisa diterbitkan pada tahun 2015 oleh Yayasan Adaro Bangun Negeri (YABN).

f. Tesis yang berjudul Pluralitas Agama Menurut Pandangan Tokoh-Tokoh Agama Kaharingan Di Kecamatan Halong Kabupaten Balangan Kalimantan Selatan karya Abdul Hamid S. Th. I, UIN Sunan Kalijaga tahun 2017.

g. Prosiding yang berjudul Negosiasi Buddhisme Dalam Ritual Aruh Baharin Dayak Halong karya Lestiana Metta \& A. Budiyanto, ICSSIS tahun 2013..

Analisis Data yang digunakan adalah analisis data interaktif. Aktivitas analisis data meliputi 3 tahapan yakni: pertama data reduction, kedua data display, dan ketiga conclusion drawing/verivication. Reduksi Data berarti merangkum data maksudnya yakni memilih hal-hal yang pokok didalam proses penelitian, memfokuskan pada halhal yang penting sesuai dengan rumusan masalah yang telah ditetapkan, mencari tema dan menentukan pola yang sesuai dengan fokus penelitian. Dengan demikian data yang direduksi akan memberikan gambaran yang jelas. Hal tersebut, diperuntukkan untuk mempermudah di 
peneliti dalam melakukan pengumpulan data pada tahap selanjutnya, dan mencarinya kembali bila diperlukan (Sugiyono, 2013: 338).

Selanjutnya, penyajian Data yaitu, data akan lebih terorganisasikan, dan tersusun dalam pola hubungan, sehingga akan semakin mudah untuk dipahami oleh di peneliti. Dengan penyajian data, maka akan memudahkan dalam memahami apa yang telah terjadi pada fenomena yang diteliti. Setelah memahaminya, langkah berikutnya merencanakan kerja selanjutnya berdasarkan apa yang telah peneliti pahami (Sugiyono, 2013: 341).

Lebih lanjut, kesimpulan awal yang dikemukakan masih bersifat umum atau sementara. Selanjutnya akan berubah bilamana ditemukan bukti-bukti yang kuat untuk mendukung pada tahap pengumpulan data berikutnya. Tetapi, bilamana kesimpulan yang dikemukakan pada tahap awal ini, didukung oleh bukti-bukti yang valid dan konsisten pada saat penelitian dilapangan, maka kesimpulan yang dikemukakan merupakan kesimpulan yang telah kredibel.

Kesimpulan di dalam penelitian kualitatif merupakan suatu temuan baru, sebelumnya belum pernah ditemukan. Temuan tersebut, dapat berupa sebuah deskripsi ataupun gambaran suatu obyek yang sebelumnya masih buram, sehingga setelah diteliti menjadi jelas. Hal itu dapat berupa hubungan kausal atau interaktif, hipotesis atau suatu teori (Sugiyono, 2013: 345).

\section{Hasil Dan Pembahasan}

\section{A. Hasil Penelitian}

Desa Kapul adalah sebuah desa yang berada di Kecamatan Halong. Secara administratif, Kecamatan Halong berada dibawah tanggungjawab pemerintah Kabupaten Balangan yang berada di teritorial Provinsi Kalimantan Selatan, Indonesia. Di Kecamatan Halong khususnya di Desa Kapul oleh Pemerintah Kabupaten Balangan pada tahun 2015 telah ditetapkan menjadi desa wisata budaya.

Menurut Hardiansyah (Ketua Desa Wisata Wadian Tambai Kapul), latarbelakang ditetapkannya Desa Kapul sebagai desa wisata budaya berawal dari kisah bupati Sefek Effendie. Pada mulanya bupati ini mengadakan reuni dengan kawan-kawannya semasa bersekolah di Sekolah Menengah Atas (SMA) di Kabupaten Balangan. Dari reuni itu diajaklah mereka semua untuk menyaksikan sebuah acara adat Dayak Meratus Halong di Desa Kapul. Kemudian dari pengalaman ini akhirnya terpikir untuk menetapkan Desa Kapul sebagai desa wisata budaya (Elhami, 2017).

Terdapat beberapa upacara keagamaan yang dimiliki oleh suku Dayak Meratus Halong. Upacara keagamaan itu meliputi: Aruh Baharin, Aruh Membatur, Ritual Balian, Ritual Adat Ngundang, Ritual Adat Perkawinan, dan masih banyak lagi 
(Eter Nabiring, 2013; 16-17: 2018: 4). Upacara Aruh Baharin merupakan sebuah hajatan besar atau pesta panen yang diadakan oleh masyarakat Dayak Meratus Halong. Secara umum, upacara aruh baharin merupakan pesta panen syukur keluarga karena hasil panen padi yang berlimpah dipahumaan (ladang) atau bisa diartikan sebagai ungkapan rasa syukur atas panen pertama di ladang baru (Eter Nabiring, 2013: 16; Hartatik, 2017: 29).

Prosesi puncak dari ritual ini terjadi pada malam ketiga hingga keenam, di mana para balian melakukan proses batandik (menari) mengelilingi tempat pemujaan dengan diiringi oleh bunyi-bunyian alat musik tradisional berupa gamelan. Perlengkapan religi dalam upacara aruh baharin, biasanya menggunakan hewan kerbau sejumlah 2-5 ekor, hewan kambing 10-15 ekor dan ayam (Eter Nabiring, 2013: 16-38). Di tambah beras sebagai perlengkapan religi terpenting ritual ini.

\section{B. Pembahasan}

\section{Aruh Baharin Identitas Religi Dayak Meratus Halong}

Setiap suku bangsa memiliki sistem religi yang dianutnya. Tak terkecuali bagi suku dayak. Menurut Koentjaraningrat yang dimaksud dengan sistem religi adalah semua aktivitas manusia yang bersangkutan dengan religi berdasarkan atas suatu getaran jiwa yang ia rasakan. Hal itu biasanya disebut sebagai emosi keagamaan, atau religious emotion (Koentjaraningrat,
2002: 377). Bagi suku dayak, sistem religi amat penting peranannya dalam kehidupan sosio-budaya dan sosio-religi mereka disamping sebagai identitas kultural yang mereka junjung secara turun-temurun. Kata Dayak adalah sebuah nama kolektif bagi sebagian besar suku bangsa yang mendiami kepulaun Kalimantan. Pada era kolonialisme, kata dayak digunakan oleh para peneliti pada masa itu dalam konotasi untuk membedakan antara penduduk Kalimantan yang muslim (melayu) dengan yang masih menganut kepercayaan leluhurnya (dayak) (Hartatik, 2017: 1).

Terdapat ratusan sub suku dayak yang tersebar di wilayah Kalimantan. Pada wilayah Kalimantan Selatan sendiri, terdapat identitas kolektif bagi suku dayak. Suku dayak tersebut, bernama Suku Dayak Meratus. Dinamakan sebagai Dayak Meratus karena suku bangsa ini tersebar dan mendiami wilayah sekitaran pegunungan meratus. Pegunungan meratus berada di wilayah provinsi Kalimantan Selatan. Dilihat dari arah mata angin, pegunungan ini memanjang dari tenggara hingga barat laut provinsi Kalimantan Selatan.

Salah satu konsentrasi hunian terpenting bagi Dayak Meratus berada di Desa Kapul, Kecamatan Halong, Kabupaten Balangan, Provinsi Kalimantan Selatan. Menurut data statistik Badan Pusat Statistik Kabupaten Balangan, Desa Kapul memiliki jumlah penduduk sekitar 1.072 jiwa. Dari total jumlah penduduk tersebut, terhitung 
masing-masing dari jumlah kepala keluarga, yaitu berjumlah sekitar 204 jiwa (BPS Kecamatan Halong, 2017: 14-15). Menurut Koentjaraningrat suatu kebudayaan suku bangsa selalu mempunyai ciri-ciri untuk sedapat mungkin memelihara emosi keagamaannya, yang meliputi: sistem keyakinan, sistem upacara keagamaan, dan orang-orang yang menganut religi itu.

Dalam sistem upacara keagamaan, secara khusus menurut pendapat Koentjaraningrat meliputi: pertama tempat prosesi upacara keagamaan berlangsung, kedua saat-saat prosesi upacara keagamaan belangsung, ketiga perlengkapan religi, keempat orang-orang yang menjalankan upacara dan yang kelima orang yang memimpin jalannya upacara keagamaan (Koentjaraningrat, 2002: 377-378).

Terdapat beberapa upacara keagamaan yang dimiliki oleh suku Dayak Meratus Halong. Upacara keagamaan itu meliputi: Aruh Baharin, Aruh Membatur, Ritual Balian, Ritual Adat Ngundang, Ritual Adat Perkawinan, dan masih banyak lagi (Eter Nabiring, 2013; 16-17: 2018: 4).

\section{Upacara Aruh Baharin}

Upacara Aruh Baharin merupakan sebuah hajatan besar atau pesta panen yang diadakan oleh masyarakat Dayak Meratus Halong. Secara terminologis, upacara aruh baharin merupakan sebuah pesta panen syukur keluarga atas hasil panen padi yang berlimpah dipahumaan (ladang). Hal itu dapat diartikan sebagai sebuah ungkapan rasa syukur atas panen pertama di ladang baru (Eter Nabiring, 2013: 16; Hartatik, 2017: 29). Menurut penuturan bapak Gupen (Tokoh Adat Dayak Meratus Halong) yang dimaksud dengan upacara aruh baharin adalah: acara pesta panan syukur, mengucapkan syukur kepada Tuhan Yang Maha Esa atas rejeki yang mereka dapatkan.

Sejalan dengan penuturan bapak Ibas (Pemangku Adat Suku Dayak Halong/Tokoh Balian) mengatakan bahwa upacara aruh baharin adalah: pesta panen mengucapkan terimakasih kepada dewa bumi, dewa kayu, dan kepada Tuhan Yang Maha Kuasa. Aruh baharin memiliki tujuan penting di dalamnya, antara lain: hajad atau Pa-antuhan yang terkabul, hajad huang/sengsara dalam kesukaran, gejala alam, panen parei/padi yang berlimpah (Eter Nabiring, 2013: 38).

Menurut penuturan bapak Gupen tujuan dilaksanakannya upacara aruh baharin sendiri bertujuan untuk: tujuan aruh baharin itu terbagi dua versi, ada yang bersifat hajat, tatkala manusia itu terdapat kesulitan-kesulitan dia berhajat, baik kepada leluhurnya atau pada Yang Maha Kuasa. Ada lagi sifatnya cita-cita usahanya sukses kalo misalnya berhasil gitu begini melimpah ruah akhirnya saya akan melaksanakan aruh adat baharin, ibarat ada rezeki harus dinikmati orang banyak, rezeki kita itu, itu pesan utama dari aruh baharin. 


\section{Tempat Dilangsungkan Upacara Aruh} Bahrain

Prosesi upacara aruh baharin berlangsung pada empat tempat pemujaan, salah satu tempat terpenting bagi masyarakat Dayak Meratus Halong adalah di balai adat Sarumpun. Namun, selain di balai adat, dapat juga dilaksanakan dirumah secara pribadi, tentunya dengan skala yang lebih kecil. Hal tersebut, seperti penuturan bapak Effendi (Sekertaris Pemerintah Desa Kapul) yaitu: bisa di rumah warga, tingkatan skalanya hanya skala kecil yang biasanya dilaksanakan selama 3 hari.

Balai adat sarumpun di bangun dengan ukuran kira-kira sekitar 10 meter $\mathrm{x}$ 10 meter. Balai adat sarumpun berlokasi di Desa Kapul, Kecamatan Halong, Kabupaten Balangan. Lokasi balai adat ini berhadapan langsung dengan Kantor Pemerintahan Desa yang ada di Desa Kapul. Untuk dibalai adat sendiri biasanya masyarakat Dayak Meratus Halong ketika berlangsungnya prosesi upacara aruh baharin mengundang para Tabib Dadukun sebanyak 20-25 orang, para Patati dan Penambuh alat ritual gandrang dan kelampat, saron, dan sebagainya (Eter Nabiring, 2013: 16-38).

\section{Prosesi dan Perlengkapan Religi Upacara Aruh Baharin}

Ritual adat aruh baharin diadakan pada bulan-bulan September s/d Oktober per tiga hingga sepuluh tahun sekali. Ritual adat ini berlangsung selama tujuh hari berturut-turut dari siang hari hingga menjelang malam hari. Menurut penuturan bapak Gupen bahwa aruh baharin itu dilaksanakan pada kurun waktu selama 5 tahun, 6 tahun, 7 tahun, bahkan bagi yang belum mampu ekonomi bisa sampai 10 tahun baru melaksanakan. Sejalan dengan penuturan bapak Ibas yaitu: kebiasaan 3 tahun sekali atau 5 tahun tergantung anggaran.

Prosesi puncak dalam ritual ini terjadi pada malam ketiga hingga keenam, di mana para balian melakukan proses batandik (menari) mengelilingi tempat pemujaan dengan diiringi oleh bunyibunyian alat musik tradisional berupa gamelan (Eter Nabiring, 2013: 16-38). Sedangkan pada hari kesatu dan kedua masyarakat Dayak Meratus Halong melakukan kegiatan berupa nyiwuwunrung yaitu berupa acara dimana anak-anak muda mengelilingi dedaunan enau muda (janur) yang akan digunakan untuk menghias balai.

Kemudian hari terakhir di hari ketujuh merupakan acara beguru atau wewarikan yaitu berupa tarian monyet seperti hanoman dalam cerita Ramayana. Pada hari terakhir ini, masyarakat Dayak Meratus Halong melakukan kegiatan memasak untuk penduduk. Makanan tersebut, berupa sesajian yang nantinya akan dimakan secara bersama-sama dimalam terakhir upacara aruh baharin (Hartatik, 2017: 29-32). Perlengkapan religi dalam upacara aruh baharin, biasanya menggunakan hewan kerbau sejumlah 2-5 
ekor, dan hewan kambing sejumlah 10-15 ekor serta ayam sebagai pelangkap (Eter Nabiring, 2013: 16-38). Di tambah lagi beras sebagai perlengkapan religi terpenting dalam ritual ini.

Hal tersebut, seperti penuturan bapak Gupen: kalo perlengkapan segi konsumsinya kan utamanya beras dulu, perlengkapan yang beras itu ditumbuk menjadi tepung akan dibikin sejenis jenang yang terdiri dari jenang kuning, jenang merah, jenang hijau, jenang biru, jenang putih, tambah lagi wajik, dan cangkaruk, serta cucur kami sebut itu, itu dari segi beras. Kalo dari hewannya pasti kerbau sudah ada, kambing, dan ayam. Ada lagi hewan dalam hutan seperti kancil dan tupai.

Sejalan dengan penuturan bapak Ibas, yang menyatakan bahwa perlengkapan religi terpenting dalam upacara aruh baharin terdiri dari hewan-hewanan, tumbuh-tumbuhan, dan yang paling utama yaitu beras sebagai syarat utama dalam ritual, yaitu: pertama sesajian bubur putih, bubur habang itu beras, yang kedua ada sesajian seperti ayam, kambing dan kerbau.

\section{Peran Tokoh Keagamaan Balian}

Ritual aruh baharin terasa sakral dikarenakan keberadaan lima hingga (Hartatik, 2017: 29) delapan orang balian (tokoh keagamaan Dayak Meratus Halong), yang setiap malam menggelar serangkaian prosesi ritual pemanggilan roh leluhur untuk ikut hadir di dalam pesta adat tersebut. Kehadiran roh leluhur tersebut, diperuntukan untuk menikmati sesajian yang telah dipersembahkan. Tokoh balian di dalam sistem religi masyarakat Dayak Meratus Halong amat penting peranannya. Dinamakan sebagai balian, karena ia adalah manifestasi seseorang yang memimpin seluruh aspek religi. Wujud manifestasi tersebut adalah berupa serangkaian upacara ritual adat Dayak Meratus Halong. Tokoh bailan sendiri, terdiri dari tingkatan tertentu, yakni: Guru Jaya, Balian Tuha, dan Balian Tengah \& Balian Anum (Eter Nabiring, 2018: 21).

Menurut bapak Gupen, peran dari tokoh balian ini adalah: tokoh balian itu orang yang mengendalikan acara ritual aruh adat dari awal sampai akhir. Ibarat di dalam suatu pasukan dia adalah komandannya, itu namanya tokoh balian. Sedangkan menurut penuturan bapak Ibas, peran dari tokoh balian sendiri adalah: perannya itu orang tertentu yang mengerjakan seperti saya para balian, ada komandannya satu. Kalo dalam bahasa Islam itu imam, sedangkan dalam bahasa dayak adalah penghulu balian.

\section{Nilai-Nilai dalam Upacara Aruh Baharin}

Upacara aruh baharin terasa penting bagi masyarakat Dayak Meratus Halong, dikarenakan upacara ini berusaha untuk menunjukan identitas kultural, kebudayaan, dan keyakinan serta kosmologi Dayak Meratus Halong. Terdapat nilai-nilai penting di dalam upacara aruh baharin, yaitu: menciptakan asas gotong-royong bagi 
sesama masyarakat, menjaga ritual nenek moyang secara turun-temurun, membentuk nilai kesopanan dan tatakrama, menjunjung nilai adat serta yang terpenting adalah mengucapkan terimakasih kepada Tuhan Yang Maha Kuasa yang telah memberikan rezeki. Dalam paparan ini, disarikan dari pendapat dari tiga orang informan berdasarkan hasil wawancara yang telah peneliti lakukan. Wawancara tersebut dilakukan kepada Bapak Effendi, Bapak Gupen, dan Bapak Ibas.

Menurut penuturan Bapak Effendi nilai-nilai dari upacara aruh baharin adalah diperuntukkan untuk menciptakan asas gotong-royong bagi sesama warga masyarakat Dayak Meratus Halong. Hal tersebut, sesuai dengan kondisi ketika berlangsungnya upacara aruh baharin, yang dimana memerlukan begitu banyak kerjasama masyarakat untuk mensukseskan serangkaian aruh adat selama tujuh hari.

Sedangkan menurut penuturan Bapak Gupen bahwa nilai-nilai dalam upacara aruh baharin itu ialah mengambil hikmah dalam melaksanakan acara ritual nenek moyang secara turun-temurun yang sifatnya tidak boleh dihilangkan. Kalau kita tidak mengerjakan akan berdampak, dalam bahasa kami itu katampuluan, bisa punggak atau tulak. Istilah yang digunakan dalam bahasa muslim yaitu kualat akan menjadi pendek umur dan berkurangnya rezeki. Ditambah lagi nilai-nilai yang lain yaitu melakukan binaan moral, bahwa kita yang melaksanakan aruh adat itu harus menjadi contoh bagi warga masyarakat, sebagai warga yang beradat, sopan santun kita di masyarakat, tatakrama dipergaulan harus terikat oleh adat yang telah disepakati secara turun-temurun. Pesan moralnya, budaya itu selalu dilaksanakan dari orang tua kalo bisa sampai yang anak-anak terus berkesinambungan jangan sampai hilang selama hatinya tergerak ataupun terpanggil untuk tetap melestarikan.

Senada dengan pendapat informan diatas dijelaskan lagi oleh Bapak Ibas, bahwa nilai-nilai dalam upacara aruh baharin yaitu pertama mengucapkan terimakasih kepada Tuhan Yang Maha Kuasa, yang telah memberikan rezeki kepada kita sesama umat manusia, lalu kepada para dewa, bumigawil dan sebagainya, serta yang terpenting mengucapkan terimakasih kepada Nining Bhatara (Tuhan Yang Maha Kuasa dalam konsep Dayak Meratus Halong) Itu kuncinya.

Dari nilai-nilai di atas, dapat di tarik kesimpulan bahwa upacara aruh baharin adalah upacara yang penting peranannya bagi masyarakat Dayak Meratus Halong. Dalam konsep mereka, nilai-nilai dari upacara aruh baharin adalah bagian dari keyakinan dan identitas kultural yang membentuk masyarakat Dayak Meratus Halong. Identitas kultural yang dijaga secara turun-temurun dan keyakinan yang dibangun melalui serangkaian ritual adat 
upacara aruh baharin telah membentuk orang Dayak Meratus Halong dari nenek moyangnya hingga saat ini terus berkesinambungan tanpa pernah putus.

\section{Penutup}

\section{Kesimpulan}

Aruh baharin adalah sebuah hajatan besar atau pesta panen padi yang diadakan oleh masyarakat Dayak Meratus Halong. Prosesi upacara aruh baharin berlangsung pada empat tempat pemujaan, salah satu tempat terpenting bagi masyarakat Dayak Meratus Halong adalah dibalai adat Sarumpun. Kegiatan dibalai adat, upacara aruh baharin berlangsung dengan skala yang lebih besar. Prosesinya diadakan selama 7 hari siang dan malam. Sedangkan untuk skala yang lebih kecil lagi, diadakan dirumah warga secara pribadi selama 3 hari siang dan malam.

Prosesi puncak dari ritual upacara aruh baharin terjadi pada malam ketiga hingga keenam, di mana para balian melakukan proses batandik (menari) mengelilingi tempat pemujaan dengan diiringi oleh bunyi-bunyian alat musik tradisional berupa gamelan. Sedangkan pada hari kesatu dan kedua masyarakat Dayak Meratus Halong melakukan kegiatan berupa nyiwuwunrung yaitu berupa acara dimana anak-anak muda mengelilingi dedaunan enau muda (janur) yang akan digunakan untuk menghias balai. Kemudian hari terakhir di hari ketujuh merupakan acara beguru atau wewarikan yaitu berupa tarian monyet seperti hanoman dalam cerita Ramayana. Pada hari terakhir ini, masyarakat Dayak Meratus Halong melakukan kegiatan memasak untuk penduduk. Makanan tersebut, berupa sesajian yang nantinya akan dimakan secara bersama-sama dimalam terakhir upacara aruh baharin (Hartatik, 2017: 29-32).

Perlengkapan religi dalam upacara aruh baharin, biasanya menggunakan hewan kerbau sejumlah 2-5 ekor, hewan kambing 10-15 ekor, ayam, dan hewanhewan yang ada didalam hutan berupa kancil dan tupai (Eter Nabiring, 2013: 1638). Di tambah lagi tumbuh-tumbuhan seperti janur dan padi sebagai perlengkapan religi terpenting dalam ritual adat ini. Dalam prosesi upacara aruh baharin, tokoh balian amat penting peranannya sebagai pemimpin spiritual masyarakat Dayak Meratus Halong. Dinamakan sebagai tokoh balian, karena ia adalah manifestasi dari seseorang yang memimpin seluruh aspek religi.

Wujud manifestasi tersebut adalah berupa pemimpin serangkaian upacara ritual adat Dayak Meratus Halong. Tokoh bailan sendiri, terdiri dari tingkatan tertentu, yakni: pertama Guru Jaya, kedua Balian Tuha, dan ketiga Balian Tengah \& Balian Anum. Nilai-nilai penting di dalam upacara aruh baharin yaitu terdiri dari: pertama menciptakan asas gotong-royong bagi sesama masyarakat, kedua menjaga ritual nenek moyang secara turun-temurun, 
ketiga membentuk nilai kesopanan dan tatakrama, keempat menjunjung nilai adat serta yang kelima yang terpenting adalah mengucapkan terimakasih kepada Tuhan Yang Maha Kuasa yang telah memberikan rezeki. Dewasa ini, nilai-nilai upacara aruh baharin sejatinya memiliki potensi untuk dapat digunakan sebagai alternatif pendidikan yang berlandaskan pada nilai budaya bagi peserta didik.

Hal itu diperuntukan untuk mengatasi persoalan berupa degradasi moral pada diri peserta didik, seperti meningkatnya pergaulan bebas, maraknya angka kekerasan, penyalahgunaan obatobatan terlarang, pornografi, dan konflik berbasis SARA yang umumnya telah menjadi permasalahan sosial. Menjadi relevan kirannya nilai-nilai diatas seperti nilai kesopanan dan tatakrama dipergaulan serta nilai-nilai gotong-royong dalam upacara aruh baharin untuk dapat membentuk moral yang baik.

Dalam hal ini tumbuh kembang dan proses pembentukan moral peserta didik. Faktor utama pembentukan moral terjadi ketika proses belajarnya dilingkungan sekolah maupun dilingkungan dimana ia tinggal. Maka nilai-nilai itulah yang sebaiknya ditanamkan kepada peserta didik, baik dilingkungan sekolah ataupun dilingkungan dimana ia tinggal.

\section{Daftar Pustaka}

2013. Kamus Populer Dayak Balangan; Dayak Balangan Tribe
Dictionary. Balangan: Dewan Adat Dayak Balangan. 1977/1978. Sejarah Daerah Kalimantan Selatan. Provinsi Kalimantan Selatan: Proyek Penelitian Dan Pencatatan Kebudayaan Daerah Pusat Penelitian Sejarah Dan Budaya Departemen Pendidikan Dan Kebudayaan. . 2000. "Masyarakat Majemuk dan Perawatannya". Jurnal Antropologi Indonesia, 63: 3. http://journal.ui.ac.id/index.php/jai /article/viewFile/3397/2678

(Diunduh pada 25 Januari 2018 pukul 09:19 WIB).

2001. "Kesetaraan Warga dan Hak Budaya Komuniti dalam Masyarakat Majemuk Indonesia". Jurnal Antropologi Indonesia, 66: 8. http://www.academia.edu/downloa d/33326033/pasudi_suparlan_keset araan_hak.pdf (Diunduh pada 25 Januari 2018 pukul 09:23 WIB).

dkk. Juli 2011. "Kearifan Lokal Tentang Mitigasi Bencana Pada Masyarakat Badui". Jurnal Makara, Sosial Humaniora, 15 (1): 67.

http://www.hubsasia.ui.ac.id/index. $\mathrm{php} /$ hubsasia/article/view/45

(Diunduh pada 16 Januari 2018 pukul 07:13 WIB).

Alfian, Magdalia. Maret 2011. "Pendidikan Sejarah dan Permasalahan Yang Dihadapi". Journal Ilmiah Kependidikan, 3 (2): 1.http://id.portalgaruda.org/?ref=br owse\&mod=viewarticle\&article $=325$ 52 (Diunduh pada 6 Mei 2016 pukul 13:29 WIB).

Anwar, Dessy. 2003. Kamus Lengkap Bahasa Indonesia. Surabaya: AMELIA Surabaya.

Baroto Waluyo, Eko. 2017. "Sumbangan Ilmu Etnobotani dalam Memfasilitasi Hubungan Manusia dengan Tumbuhan dan Lingkungannya". 
Jurnal Biologi Indonesia, 7 (2): 382. http://e-

journal.biologi.lipi.go.id/index.php/j urnal_biologi_indonesia/article/dow nload/3122/2709 (Diunduh pada 25 Januari 2018 pukul 09:33 WIB).

BPS. 2017. Kecamatan Halong Dalang Angka; Halong Subdistrict in Figures 2017. Balangan: BPS Kabupaten Balangan.

Cecep Eka Permana, Raden. 2010. Kearifan Lokal Masyarakat Baduy Dalam Mintigasi Bencana. Jakarta: Penerbit Wedatama Widya Sastra.

Darmadi, Hamid. 2014. Metode Penelitian Pendidikan dan Sosial; Teori Konsep Dasar dan Implementasi. Bandung: Penerbit Alfabeta.

Elhami. 14 Februari 2017. "Kapul, Desa Wisata Budaya Komunitas Dayak Meratus Halong di Balangan". http://kalteng.tribunnews.com/201 7/02/14/kapul-desa-wisatabudaya-komunitas-dayak-meratushalong-di-balangan (Diakses pada 27 Mei 2018 pukul 17:24 WITA).

F. Meutia, Swasono. 2006. "Antropologi Dan Integrasi Nasional". Jurnal Antropologi Indonesia, 30 (1): 109. http://journal.ui.ac.id/index.php/jai /article/viewArticle/3557 (Diunduh pada 16 Januari 2018 pukul 06:38 WIB).

Frianti Ristiana, Ari \& Soebijantoro. Januari 2014. "Cerita Sejarah Dan Peranan Nilai-Nilai Moral (Studi Kasus Di Desa Pandean Kecamatan Mejayan Kabupaten Madiun)". Journal Agastya, 4 (1): 54.

Hamid, Abdul. 2017. "Pluralitas Agama Menurut Pandangan Tokoh-Tokoh Agama Kharingan Di Kecamatan Halong Kabupaten Balangan Kalimantan Selatan. Tesis. Yogyakarta: UIN Sunan Kalijaga. (http://digilib.uinsuka.ac.id/28532/1/1520510064_B AB-I_IV-atau-V_DAFTAR-
PUSTAKA.pdf Diunduh pada 16 Januari 2018 pukul 07:20 WIB).

Hartatik. 2017. Jejak Budaya Dayak Meratus Dalam Perspektif Etnoreligi. Yogyakarta: Penerbit Ombak.

Helmawati. 2014. Pendidikan Keluarga; Teoretis Dan Praktis. Bandung: Penerbit PT Remaja Rosdakarya.

http://balitbangda.kalselprov.go.id/kearifa n-lokal-masyarakat-dayak-meratusdi-kalimantan-selatan-dalammendukung-ketahanan-pangan/ (Diunduh pada 8 Mei 2016 pukul 09:10 WIB).

J. Moleong, Lexy. 2012. Metodologi Penelitian Kualitatif. Bandung: PT Remaja Rosdakarya.

Kahmad, Dadang. 2003. Sosiologi Agama. Bandung: Penerbit PT Remaja Rosdakarya.

Koentjaraningrat. 2002. Pengantar Ilmu Antropologi. Jakarta: PT RENIKA CIPTA.

Maxdjoyo. 2015. "Definisi Pendidikan". http://www.kompasiana.com/maxd joyo/definisi-pendidikan (Diakses pada 15 Juni 2015 pukul 16:40 WIB).

Metta, Lestiana \& A. Budiyanto. 2013. "Negosiasi Buddhisme Dalam Ritual Aruh Baharin Dayak Halong". Prosiding ICSSIS. (https://icssis.files.wordpress.com/ 2013/09/2013-01-28.pdf Diunduh pada 15 Juni 2018 pukul 12:01 WIB).

Nabiring, Eter. 2018. Ritual Adat \& Cerita Rakyat Dayak Halong. Malang: Nomaden Institute Cross Cultural Studies \& Penerbit Kota Tua.

Norpikriadi. 2015. Sejarah, Etnisitas, Dan Kebudayaan Banjar. Yogyakarta: Penerbit Ombak Dua.

PaEni, Mukhlis. 2009. Sejarah Kebudayaan Indonesia; Sistem Teknologi. Jakarta: Rajawali Pers. 
Pajriah, Sri \& Mia Sumiari Dewi. Maret 2014. "Upacara Adat "Merlawu" Di Gunung Susuru Desa Kertabumi Kecamatan Cijeungjing Kabupaten Ciamis". Jurnal Artefak, 2 (2): 196. (https://jurnal.unigal.ac.id/index.ph p/artefak/article/view/331

Diunduh pada 16 Januari 2018 pukul 11:20 WIB).

Patilima, Hamid. 2013. Metode Penelitian Kualitatif. Bandung: Penerbit Alfabeta.

Purwaningsih, Endang. April 2010. "Keluarga Dalam Mewujudkan Pendidikan Nilai Sebagai Upaya Mengatasi Degradasi Nilai Moral". Journal Pendidikan Sosiologi dan Humaniora, 1 (1): 44-46. http://id.portalgaruda.org/?ref=bro wse $\&$ mod=viewarticle $\&$ article $=335$ 99 (Diunduh pada 6 Mei 2016 pukul 17:12 WIB).

Saleh, M. Idwar. (tanpa tahun terbit). Sejarah Banjarmasin; Seri Monografi 3. Bandung: K. P. P. K. Balai Pendidikan Guru.

Setiadi, Elly M, dkk. 2006. Ilmu Sosial Dan Budaya Dasar. Jakarta: Penerbit Kencana Prenada Media Group.

Sugiyono. 2013. Metode Penelitian Kualitatif; Kualitatif dan $R \& D$. Bandung: Penerbit Alfabeta.

Sulton. 2015. "Menimbang Peran Pendidikan di Sekolah sebagai Wahana Pembentukan Karakter Siswa". Makalah disampaikan dalam Seminar Nasional Pendidikan, FKIP Universitas Muhammadiyah Ponorogo, Ponorogo, 37-38.

Suparlan, Parsudi. 1999. "Kemajemukan, Hipotesis Kebudayaan Dominan dan Kesukubangsaan". Jurnal Antopologi Indonesia, 58: 16-18. http://journal.ui.ac.id/index.php/jai /article/download/3368/2652 (Diunduh pada 25 Januari 2018 pukul 09:17 WIB).
Suryadinata, Leo. 2003. "Kebijakan Negara Indonesia terhadap Etnik Tionghoa; Dari Asimilasi ke Multikulturalisme ?". Jurnal Antropologi Indonesia, 71: 4.

http://journal.ui.ac.id/index.php/jai /article/viewPDFInterstitial/3464/ 2744 (Diunduh pada 25 Januari 2018 pukul 09:16 WIB).

Wajidi. Mei 2013. "Kearifan Lokal Masyarakat Dayak Meratus Di Kalimantan Selatan Dalam Mendukung Ketahanan Pangan". BALITBANGDA PROV. KALSEL, : 8990. 